\section{ANALYZING POLITICAL AND SYSTEMIC DETERMINANTS OF FINANCIAL RISK IN LOCAL GOVERNMENTS}

\section{Andrés NAVARRO-GALERA \\ Juan LARA-RUBIO \\ Dionisio BUENDÍA-CARRILLO \\ Salvador RAYO-CANTÓN}

\section{Andrés NAVARRO-GALERA}

Professor, Department of Financial Economics and Accounting, Faculty of Economics and Business Studies (Campus Cartuja), University of Granada, Granada, Spain

E-mail: angalera@ugr.es

\section{Juan LARA-RUBIO}

Associate Professor, Department of Financial Economics and Accounting, Faculty of Economics and Business Studies (Campus Cartuja), University of Granada, Granada, Spain Tel.: 0034-687-125.767

E-mail: juanlara@ugr.es

\section{Dionisio BUENDÍA-CARRILLO}

Associate Professor, Department of Financial Economics and Accounting, Faculty of Economics and Business Studies (Campus Cartuja), University of Granada, Granada, Spain E-mail: dbuendia@ugr.es

\section{Salvador RAYO-CANTÓN}

Associate Professor, Department of Financial Economics and Accounting, Faculty of Economics and Business Studies (Campus Cartuja), University of Granada, Granada, Spain E-mail: srayo@ugr.es

\section{Abstract}

Studies have shown that political variables can influence the volume of government debt and have recommended investigating the joint effects of diverse factors on the risk of local government default. Considering the relation between economic management and political constraints, this paper examines the joint influence of political and systemic factors on the risk of loan default by Spanish local governments. To do so, we analyze 148 city councils for the period 2006-2011, using a logit model with panel data and an artificial neural network.

The empirical results indicate that the financial risk of local governments is affected both by political factors specific to each case and, simultaneously, by systemic variables for the country. Specifically, political variables such as the mayor not having economics-related university studies, the under-representation of female councilors in the municipal corporation, municipal government by a party with a progressive ideology, and ideological alignment between the municipal and the regional government are all associated with greater financial risk. Moreover, rising national unemployment, an increased sovereign risk premium, the impact of the electoral cycle, and that of declining economic growth are all factors that may increase the risk of default. The findings presented are of great potential interest for governments, managers, national and international fiscal authorities, financial regulators, and citizens at large, because an understanding of the significance of these variables can help authorities make appropriate decisions to prevent and/or overcome problems related to municipal insolvency.

Keywords: default risk, local governments, political factors, systemic factors. 


\section{Introduction}

The economic recession that began in 2008 led to high levels of bank debt and budget deficits in the public sector, reducing solvency and restricting access to the credit market, as well as jeopardizing the sustainability of public services. The debt crisis produced great concern about credit risks, among policymakers, financial regulators, and fiscal authorities. Researchers concluded that it was necessary to study the causes of high levels of local government (LG) default in order to design and implement corrective and preventive policies and thus put government finances on a sound footing and in a position to meet debt and deficit targets (Aldasoro and Seiferling, 2014; World Bank Group, 2015; European Commission, 2012; Council of the European Union, 2011; Federal Accounting Standards Advisory Board, 2018; Navarro-Galera et al., 2015; Balaguer-Coll, Prior and Tortosa-Ausina, 2016; Beetsma and Vermeylen, 2007).

The debt crisis has been particularly worrying in countries such as Italy, Ireland, Portugal, Greece, and Spain. International organizations have concurred with academic studies that public debt in these countries is of such a magnitude that major problems of repayment may arise and that there are worrying differences between public revenue and expenditure (European Commission, 2012; Aldasoro and Seiferling, 2014; Balaguer-Coll, Prior and Tortosa-Ausina, 2016; Navarro-Galera et al., 2015).

In this context, taking into account that financial institutions are the main creditors of LGs, researchers have considered it especially interesting to study the risk of loan default (Arbatli and Escolano, 2015; Balaguer-Coll, Prior and Tortosa-Ausina, 2016; Elgin and Uras, 2013; Guillamón, Bastida and Benito, 2011). Various studies, including Balaguer-Coll, Prior and Tortosa-Ausina (2016), Elgin and Uras (2013) and Geys and Revelli (2011), have analyzed the influence of variables such as absolute majority government and political fragmentation on the volume of bank debt and on sustainability. However, these papers examined only individual factors pertaining to each LG and did not address the causes of default risk.

Despite the valuable conclusions presented in the above papers, many organizations in the field of public finances argue that a comprehensive analysis of government credit risk should include, besides political factors (which are specific to each entity and may be dependent on election outcomes), systemic ones, such as the macroeconomic cycle, fiscal policy, and the electoral cycle, in view of the vulnerability of individual government entities to macroeconomic changes and the volatility of non-controllable variables (Aldasoro and Seiferling, 2014; Local Government Association of South Australia, 2019; Federal Accounting Standards Advisory Board, 2014; World Bank Group, 2015; US Department of the Treasury, 2013).

In view of the above considerations, the aim of this paper is to advance our understanding of the factors that influence LG credit risk. Assuming an interconnection between political decisions and economic management, we study the joint effects of political and systemic variables on the probability of bank loan default, following the Basel II rules (BCBS, 2006). To do so, we analyze 148 large Spanish LGs during the period 2006-2011, using a logit model with panel data and an artificial neural net- 
work. From the results obtained, we identify political and systemic factors underlying the risk of LG insolvency. The conclusions drawn provide useful new knowledge for policymakers, managers, financial analysts, regulators, national and international tax authorities, voters, users of public services, citizens at large, and other stakeholders.

\section{The impact of political and systemic variables on credit risk under Basel II rules}

We study the causes of credit risk by considering the probability of default (PD) as a financial indicator. In line with previous research in this field, our analysis takes into account the definition of default, or breach of bank payment commitments, established by the Basel II Banking Supervision Committee (Castrén, Dées and Zaher, 2010; Bluhm and Overbeck, 2003; Gordy, 2003), according to which a higher probability of default is associated with a greater expected loss, a greater need for capital and, therefore, a higher risk-adjusted rate of interest.

Considering the different default scenarios considered under Basel II, our study incorporates a dependent variable addressing these possibilities through an ability-to-pay process (APP), which measures LGs' capacity to meet their credit liabilities (Bluhm and Overbeck, 2003). This APP depends on the quality of LG assets and financial resources and is a latent random variable that is not directly observable, but which can be estimated using a nonlinear discrete-choice approach, namely the logit panel data model, which is an appropriate means of considering the factors that contribute to the likelihood of debt default (Bonfim, 2009; Jacobson, Lindé and Roszbach, 2013). In addition, to study the phenomenon of government insolvency, we construct an artificial neural network (ANN), in the knowledge that previous researchers have used ANNs as a complement and an advance on parametric techniques. In most cases, this approach enhances the analytical process.

In this respect, the standard known as Basel II (BCBS, 2006) is a highly significant advance in the international financial system as this model helps ensure the soundness and stability of credit institutions, making it possible to assess the financial risks associated with the institutions, such as governments, to which these entities make loans. In particular, the Basel II model seeks to ensure that banks implement new tools to strengthen the capital requirements arising from their credit risk operations, focusing both on the market and on operational aspects. Accordingly, the model proposes tools with which financial institutions can estimate the default risk on the loans made to their customers.

According to Gordy (2003), a local government (LGi) is in default if its ability to pay at any given time $A P P_{i t}$ is below a certain level of credit liability $\left(c_{i t}\right)$. Under this approach, default by $L G_{i}$ in the period $t$ is a random dichotomous variable $Y_{i t}$ such that:

$$
Y_{i t}=\left\{\begin{array}{l}
1 \text { if the } L G \text { defaults at time tor } A P P_{i t} \leq c_{i t} \\
0 \text { if the } L G \text { does not default at time tor } A P P_{i t}>c_{i t}
\end{array}\right\}
$$

where the probability of $L G_{i}$ default at time $t$ is equal to

$$
P D_{i t}=P\left(Y_{i t}=1\right)=P\left(A P P_{i t} \leq c_{i t}\right)
$$


Following the methods used in previous studies of credit risk in the business sector (Castro, 2013; Mileris, 2012), we analyze two types of credit risk factor, as variables expected to influence the probability of default: political factors and systemic factors. Political factors impacting on credit risk $\left(\mathrm{Z}_{\mathrm{it}}\right)$ are specific to each local government. In contrast, systemic credit risk factors $\left(X_{t}\right)$ include aspects of the macroeconomic cycle, fiscal policy, and the electoral cycle, with respect to the country.

In this paper, the following initial premises are assumed: (1) local governments form a homogeneous segment within the public sector; (2) the systemic factors $\mathrm{X}_{\mathrm{t}}$ that influence credit risk affect all local governments at time $t(t=1, \ldots, T)$; (3) the idiosyncratic political factors $\mathrm{Z}_{\mathrm{it}}(\mathrm{i}=1, \ldots, \mathrm{Nt}, \mathrm{t}=1, \ldots, \mathrm{T})$ that influence credit risk individually affect each $\mathrm{LG}_{\mathrm{i}}$; (4) the idiosyncratic LG factors (individual or LG-specific factors) are not entirely independent of systemic effects, an aspect that is particularly significant in economic recessions (Bonfim, 2009). Thus, the $\mathrm{APP}_{\text {it }}$ variable of the $\mathrm{i}$-th LG at time $\mathrm{t}$ is a function of the political and systemic variables, as in expression (3):

$$
A P P_{i t}=\alpha+\beta_{j} X_{t}+\delta_{k} Z_{i t}+u_{i t}
$$

where $\beta_{\mathrm{j}}$ and $\delta_{\mathrm{k}}$ are the parameter vectors estimated by a linear panel data model and $u_{i t}$ is the random perturbation. Then, following Rösch (2003) and Bonfim (2009) a borrower $\mathrm{L}_{\mathrm{g}}$ is considered to be unpaid if its $\mathrm{APP}_{\text {it }}$ falls below the level $\mathrm{c}_{\mathrm{it}}$ (credit obligations). Although the variable $\mathrm{APP}_{\text {it }}$ is latent and not directly observable, the explanatory variables $\mathrm{X}_{\mathrm{t}}$ and $\mathrm{Z}_{\mathrm{it}}$ and the systemic and political factors, together with the independent binary variable $Y_{\mathrm{it}}$, the indicator of default, are directly observable, from the sample data.

In our study, credit risk was determined via the estimation of $\mathrm{PD}$, using a logistic regression model and an ANN. This procedure was adopted for several reasons. First, discrete-choice models are held to be appropriate when the research aim is to analyze the determinants of the probability of an individual economic agent (Jacobson, Lindé and Roszbach, 2013). Second, the two models we use meet all the statistical requirements specified in the Basel II rules (BCBS, 2006) and in Bank of Spain Circular 3/2008 for calculating PD. Third, the European Commission (2015), Aldasoro and Seiferling (2014), the World Bank Group (2015) and the US Department of the Treasury (2013) have all recognized the need to study the joint effect of idiosyncratic factors (or individual ones, for a single entity) and systemic factors (such as the macroeconomic cycle, fiscal policy, and the electoral cycle) in the measurement of government credit risk.

\section{Research method}

\subsection{Sample selection}

This empirical study focuses on large LGs in Spain, in the view that international organizations (European Commission, 2012; Aldasoro and Seiferling, 2014) and previous research (Balaguer-Coll, Prior and Tortosa-Ausina, 2016; Navarro-Galera et al., 2015; Guillamón, Bastida and Benito, 2011) have all concluded that bank debt in local 
and regional governments in Spain is too high (in fact, it is among the highest in the Eurozone).

Following Guillamón, Bastida and Benito (2011) and the criteria of the Local Government Modernization Act no. 57/2003, we selected 148 municipalities, all with over 50,000 inhabitants or, otherwise, provincial capitals, taking data for the period 20062011, i.e., from three years before the economic crisis until three years after its appearance.

This sample is appropriate for our research aim for the following reasons: (a) the introduction to the Local Government Rationalization and Sustainability Act no. 27/2013 recognizes that large LGs present major problems of insolvency and deficient financial management; (b) these governments have a large volume of bank debt (Bank of Spain, 2014; Beetsma and Vermeylen, 2007); (c) the European Comission (2012) and credit rating agencies such as Moody's (2013) have observed that the financial situation of large LGs in Spain is one of the most alarming in the Eurozone, and (d) the governments selected for analysis account for over 38.7 per cent of all LG spending and represent 56 per cent of the Spanish population; moreover, they offer a wide range of services, including public transport, local police, wastewater treatment, waste disposal and sports facilities (IGAE, 2014; Fundación La Caixa, 2014).

\subsection{The dependent variable}

In this study, the dependent variable is the $\mathrm{Y}_{\mathrm{it}}$ of the LGs in the sample, assessed according to the four financial indicators that determine when $\mathrm{APP}_{\mathrm{i}}$ is lower than the credit liability, according to the definition of default in the Basel II rules and in accordance with Spanish legislation on local government (Royal Legislative Decree 2/2004, of 5 March, approving the consolidated text of the Local Finance Regulatory Act). Hence, following the criteria used in previous studies of local government finance (Moody's, 2013, 2008; Navarro-Galera et al., 2015), we assume that $\mathrm{APP}_{\mathrm{i}}$ is lower than the credit liability and, therefore, that a local government is at risk of default (or at risk of defaulting on loan repayment obligations) when it meets at least one of the situations identified by the four financial indicators stipulated in Table 1, in line with the recommendations of the BCBS (2006).

\subsection{The independent variables}

Table 2 shows the political and systemic variables analyzed jointly in this study, together with their definitions and the expected sign of the relationship between the explanatory variables and PD. As discussed below, these variables were selected taking into account previous research on LG debt and ratings (Gaillard, 2009) and the classification of factors generally used by the credit rating agencies S\&P's $(2011,2009)$ and Moody's (2013, 2008). 


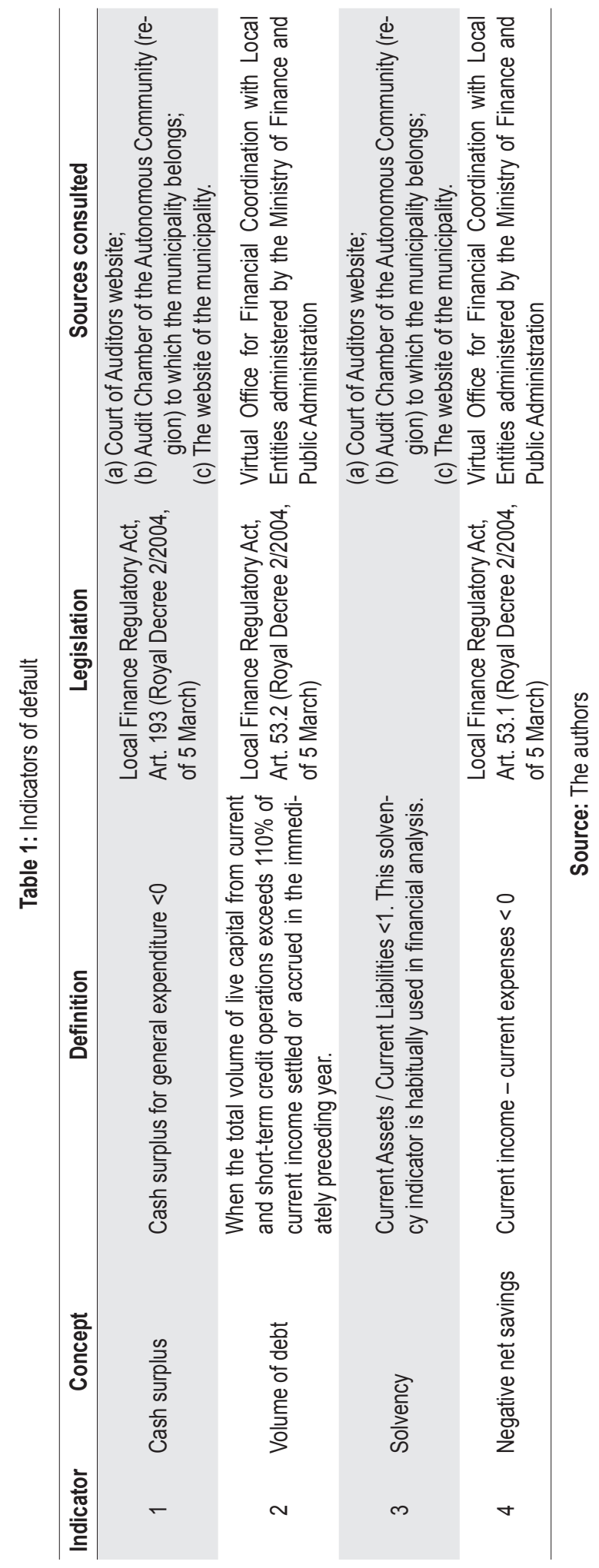




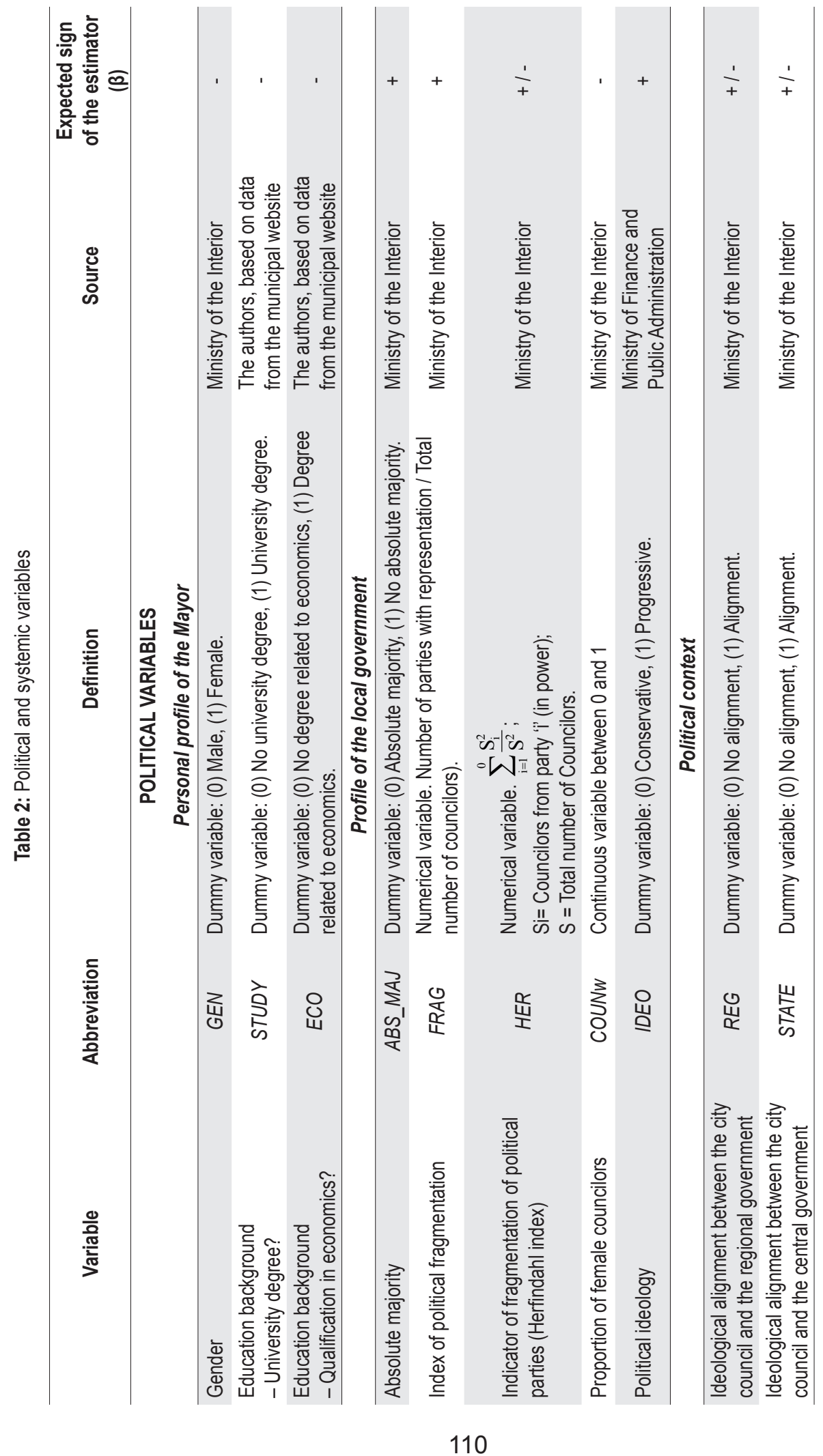




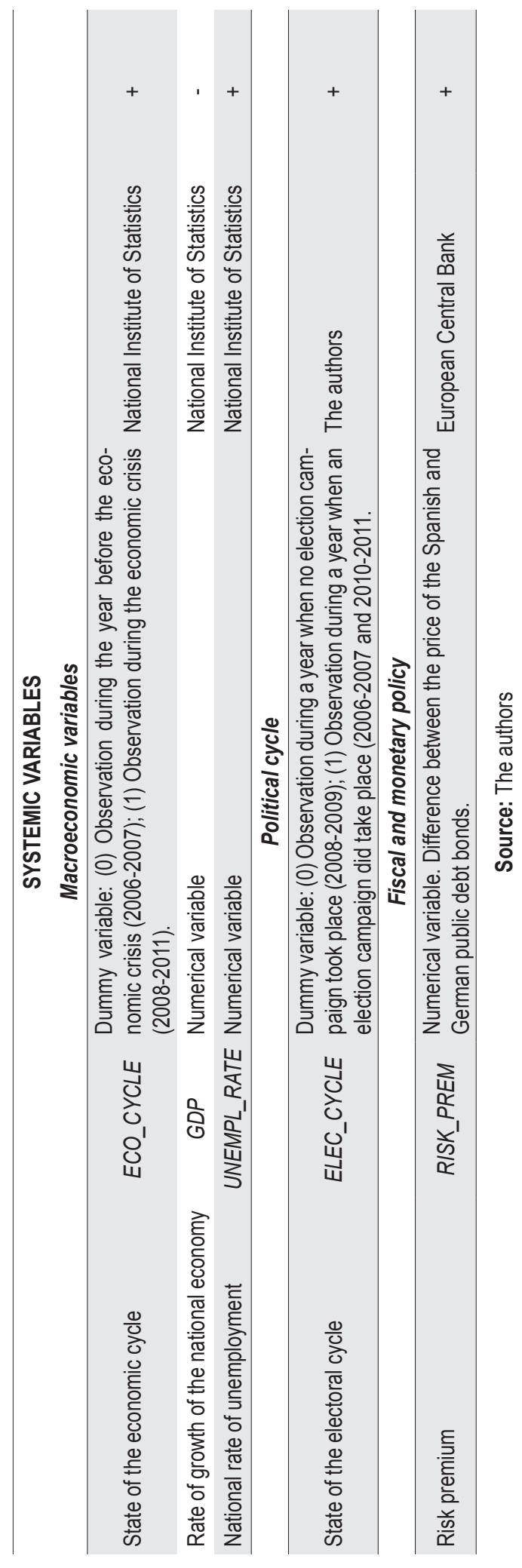




\subsubsection{Political variables}

With respect to the first group of political variables, i.e., the profile of the mayor, Ryan, Pini and Brown (2005) studied the implications of different leadership styles on innovation in LGs. In this area, neither Massolo (1991) nor Guillamón, Bastida and Benito (2011) found any evidence that the mayor's gender might influence the evolution of the volume of LG debt. In the present study, following Navarro-Galera et al. (2017) and Benito, Bastida and Muñoz (2010), we include three possible explanatory variables with respect to the mayor's profile: gender, university background and academic profile (studies related to economics). Based on previous research findings, we expected a negative relationship between these variables and PD, i.e. when the mayor is male, has no university degree or has a degree in a subject unrelated to economics, each of these circumstances will increase PD.

Regarding the LG profile, we selected five variables for analysis, in line with previous research findings. In this respect, Lago and Lago (2009) and Ashworth, Geys and Heyndels (2005) all concluded that political competition (defined as the absence of an absolute majority in the municipal corporation) is associated with greater fiscal pressure, higher levels of deficit and debt, and fewer available resources. These findings suggest that political competition may have a harmful impact on PD. Taking into account that political competition could increase the volume of debt, we expect to find a positive sign in the corresponding estimator; in other words, governments with no absolute majority are more likely to experience loan default.

Geys and Revelli (2011) and Roubini and Sachs (1989) concluded that greater political fragmentation can worsen the budget deficit and, therefore, increase municipal debt. Consequently, we examine the specific influence of this variable on PD and expect to obtain a positive sign in the estimator, showing that the greater the fragmentation, the greater the PD.

Various studies (Cabaleiro-Casal and Buch-Gomez, 2015; Guillamón, Bastida and Benito, 2011; Lago and Lago, 2009; Ryan, Pini and Brown, 2005; Ashworth, Geys and Heyndels, 2005) have concluded that greater strength in the governing political party is associated with higher levels of debt and deficit. However, Galli and Padovano (2002) found that a lower degree of political strength leads to greater indebtedness and, therefore, to greater difficulty in meeting loan maturities. To resolve this question, we use the Herfindahl index to examine whether the political strength of the governing party affects PD; in this respect, either a positive or a negative sign may be expected in the estimator.

Another interesting political factor is that of gender. Piotrowski and Van Ryzin (2007) and Jennings (1983) concluded that male councilors tend to present a more active political commitment than their female counterparts. In another study, Geys and Revelli (2011) observed that the presence of a higher proportion of women in the governing party is associated with higher municipal tax revenues, which suggests that the fiscal pressure and the deficit would be lower in these cases. Although the latter studies did not analyze the influence of the percentage of female councilors on PD, 
their findings suggest that this variable may be of interest, and therefore we included it for analysis, expecting a negative sign in the estimator, in the sense that the greater presence of women in the governing party would be associated with a lower PD.

According to some studies, the political ideology of the governing party (conservative versus progressive) can influence financial decision making (Cabaleiro-Casal and Buch-Gomez, 2015; Bastida, Benito and Guillamón, 2009). In this respect, Balaguer-Coll, Prior and Tortosa-Ausina (2016) and Bel and Miralles (2010) concluded that left-wing parties are more likely than conservative ones to adopt expansive spending policies, thus increasing levels of debt and leading to greater difficulties in meeting payment obligations. Therefore, for this variable we expect to find a positive sign in the estimator.

Finally, Solé-Ollé and Sorribas-Navarro (2008) studied variables related to the political context and reported finding a positive relationship between the ideological alignment of local and regional governments and the volume of transfers received. This circumstance could reduce the need for debt and, consequently, the risk of insolvency. However, Bastida, Benito and Guillamón (2009) recorded a negative influence between this ideological alignment on spending and fiscal revenues. In the present study we analyzed two variables, corresponding to the ideological alignment of the local government with the regional government and with the central government, expecting to find that, in each case, this would increase PD.

\subsubsection{Systemic variables}

Regarding macroeconomic variables related to the political cycle and to monetary and fiscal policy, Van Der Burgt (2009) argued that, under the Basel II regulatory framework, PD should be calculated as a long-term average of default rates, in the view that this time scale corresponds to that of the economic cycle. Therefore, and following Balaguer-Coll, Prior and Tortona-Ausina (2016), we employed a dichotomous variable (the economic cycle) that defines the periods of expansion or recession of macroeconomic indicators. The latter authors suggested that this variable could influence the volume of debt and be related to LG insolvency; as such, this variable was included for analysis as a possible determinant of PD, and its sign was expected to be positive (thus, in the years of economic expansion, PD would be lower). In addition, Arbatli and Escolano (2015), Navarro-Galera et al. (2015) and Balaguer-Coll, Prior and Tortona-Ausina (2016) have suggested that a higher level of economic activity and a higher rate of national unemployment may be associated with increased LG debt. Therefore, our empirical study included the variables rate of growth of the national economy (GDP) and rate of unemployment, expecting a negative sign in the first case and a positive one in the second.

The electoral cycle has also been identified as one that may influence LG spending. According to Blais and Nadeau (1992), LGs spend more in the years preceding electoral processes and less in post-electoral years, which could affect levels of government deficit and debt. If this were so, the electoral cycle could affect PD, and we included 
this variable for analysis, expecting a positive sign for its estimator. Finally, statements by agencies such as the IMF (Aldasoro and Seiferling, 2014) and the European Commission (2015), as well as previous research findings (Mackey, 2014) suggest that the national risk premium should be included for analysis, and that a positive sign should be expected, i.e. a higher risk premium is associated with a greater likelihood of loan default.

\subsection{Statistical models}

The empirical results required to calculate local government PD were obtained using a parametric technique, that of logistic regression with panel data, together with a non-parametric one with a particular ANN, the multilayer perceptron (MLP).

The main purpose of our logistic regression model is to accurately predict the outcome category for individual cases, using the most parsimonious model. To achieve this goal, we designed a model that included all the variables expected to be useful for predicting the dependent variable. The variables can be introduced into the model by stepwise regression, following the order specified in previous studies, and testing the fit of the model after the inclusion of each coefficient.

The logit panel data parametric technique is used to analyze the correlation between unobserved factors. According to Train (2003), this approach eliminates the bias derived from the existence of unobservable and time-invariant heterogeneity, making it very appropriate for the characteristics of our sample. Since the dependent variable is binary, and starting from equations (2) and (3) presented in section 2, the relationship between the dependent variable and the risk factors can be established by means of a logit model with panel data, which makes it possible to estimate the probability of default by $L G_{i}$ at time $t$ as a function of political and systemic factors according to expression (4), where the parameters and are obtained by maximizing the value of the likelihood function.

$$
P D_{i t}\left(A P P_{i t} \leq c_{i t} \mid X_{t}, Z_{i t}\right)=\frac{e^{\left(\hat{\alpha}+\widehat{\beta}_{j} X_{t}+\widehat{\delta}_{k} Z_{i t}\right)}}{1+e^{\left(\hat{\alpha}+\widehat{\beta}_{j} X_{t}+\widehat{\delta}_{k} Z_{i t}\right)}}
$$

Next, a particular artificial neural network, the MLP, was designed with a sigmoid activation function, calculated with the logistic activation function. This is also used in the hidden layer of the MLP, taking arguments of real value and transforming them into the range $(0,1)$. The output layer contains the target (dependent) variables. Accordingly, the output of the neural network, from a vector of inputs $\left(x_{1}, \ldots, x_{p}\right)$, is:

$$
\hat{y}=g\left(w_{0}+\sum_{h=1}^{H} w_{h} g\left(v_{0 h}+\sum_{j=1}^{p} v_{i h} x_{j}\right)\right)
$$

Finally, we designed two statistical models with the following characteristics: (a) in Model 1, the independent variables are exclusively the political variables (pro- 
file of the mayor, profile of the government and political context); (b) in Model 2, the independent variables are the same political variables plus the systemic ones (macroeconomic variables, electoral cycle, and fiscal policy).

\section{Analysis of the results}

Our empirical results show that 486 cases ( 54.73 per cent) met the default condition, and that 402 (45.27 per cent) did not. Table 3 shows the estimated coefficients transformed into odds ratios or $\operatorname{Exp}(\beta)$ of the logistic regression with random effects, both for Model 1 (political variables) and for Model 2 (political and systemic variables).

Table 3: Variables included in the logit data panel model

\begin{tabular}{|c|c|c|c|c|c|c|}
\hline \multirow{2}{*}{ Variable } & \multicolumn{3}{|c|}{ MODEL 1} & \multicolumn{3}{|c|}{ MODEL 2} \\
\hline & Coef. $(\beta)$ & Std. Err. & $\operatorname{Exp}(\beta)$ & Coef. ( $\beta$ ) & Std. Err. & $\operatorname{Exp}(\beta)$ \\
\hline ECO & $-0.532984^{(*)}$ & 0.225101 & 0.586851 & $-0.560156(*)$ & 0.256441 & 0.571119 \\
\hline COUNw & $-0.3050111^{(* *+1)}$ & 0.010912 & 0.737114 & $-0.326942^{(* * *)}$ & 0.027350 & 0.721126 \\
\hline IDEO & $0.535823^{(m+n)}$ & 0.161321 & 1.708855 & $0.550748^{(m+4)}$ & 0.202082 & 1.734550 \\
\hline REG & $0.813490^{(* *)}$ & 0.155750 & 2.255767 & $0.792837^{(*)}$ & 0.187701 & 2.209656 \\
\hline GPD & & & & $-0.129452^{(* *)}$ & 0.106566 & 0.878577 \\
\hline UNEMPL_RATE & & & & $-0.164493^{(+*+)}$ & 4.800214 & 0.848324 \\
\hline RISK_PREM & & & & $2.135564^{(+*+)}$ & 3.195407 & $8.46181 \varepsilon$ \\
\hline C_ELECT & & & & $0.279005^{(+* *)}$ & 0.379201 & 1.321814 \\
\hline cons & $-1.39932^{(+* *)}$ & 0.4681596 & & $-1.854608^{(* * *)}$ & 1.648971 & \\
\hline $\begin{array}{r}\text { Wald } \\
\text { Ch } \\
\text { Hausma }\end{array}$ & $\begin{array}{l}\text { likelihood: } 286 \text {. } \\
\text { quare: } 89.52 ; \text { si } \\
\text { lare: } 39.52 ; \text { sig.: } \\
\text { 78) test: } 12.11 \text { : }\end{array}$ & $\begin{array}{l}2 \\
y .: 0.000 \\
0.000 \\
\text { sig.: } 0.1297\end{array}$ & & $\begin{array}{r}\text { Log likel } \\
\text { Wald chi-squar } \\
\text { Chi-square: } \\
\text { Hausman (1978) }\end{array}$ & $\begin{array}{l}\text { od: } 237.44 \\
81.56 \text {; sig.: } \\
.08 \text {; sig.: } 0 . \\
t: 11.74 \text { : sig }\end{array}$ & $\begin{array}{l}.000 \\
0 \\
0.1353\end{array}$ \\
\hline
\end{tabular}

Note: ${ }^{(*)},{ }^{(*)},{ }^{(* *)}$ represent significance at the 10 per cent, 5 per cent and 1 per cent levels.

Source: The authors

The MLP results for the normalized importance of each variable (Figure 1) show that stronger weights are assigned to systematic variables and other variables found to be significant when logistic regression by panel data is applied. Therefore, the variables included as significant in Table 3 are those with the greatest explanatory capacity of local government $\mathrm{PD}$, which demonstrates the robustness of the values and signs obtained.

Moreover, as shown in Table 5, the inclusion of systemic factors in the credit risk analysis significantly improved the logistic regression panel data results obtained, from 69.26 per cent correct classification in Model 1 to 72.18 per cent in Model 2. The classification matrix values obtained by the ANN were 72.97 per cent correct for Model 1 and 74.89 per cent for Model 2. Consequently, including systemic variables and making use of an ANN design to calculate PD improved the correct classification by 5.63 percentage points. 


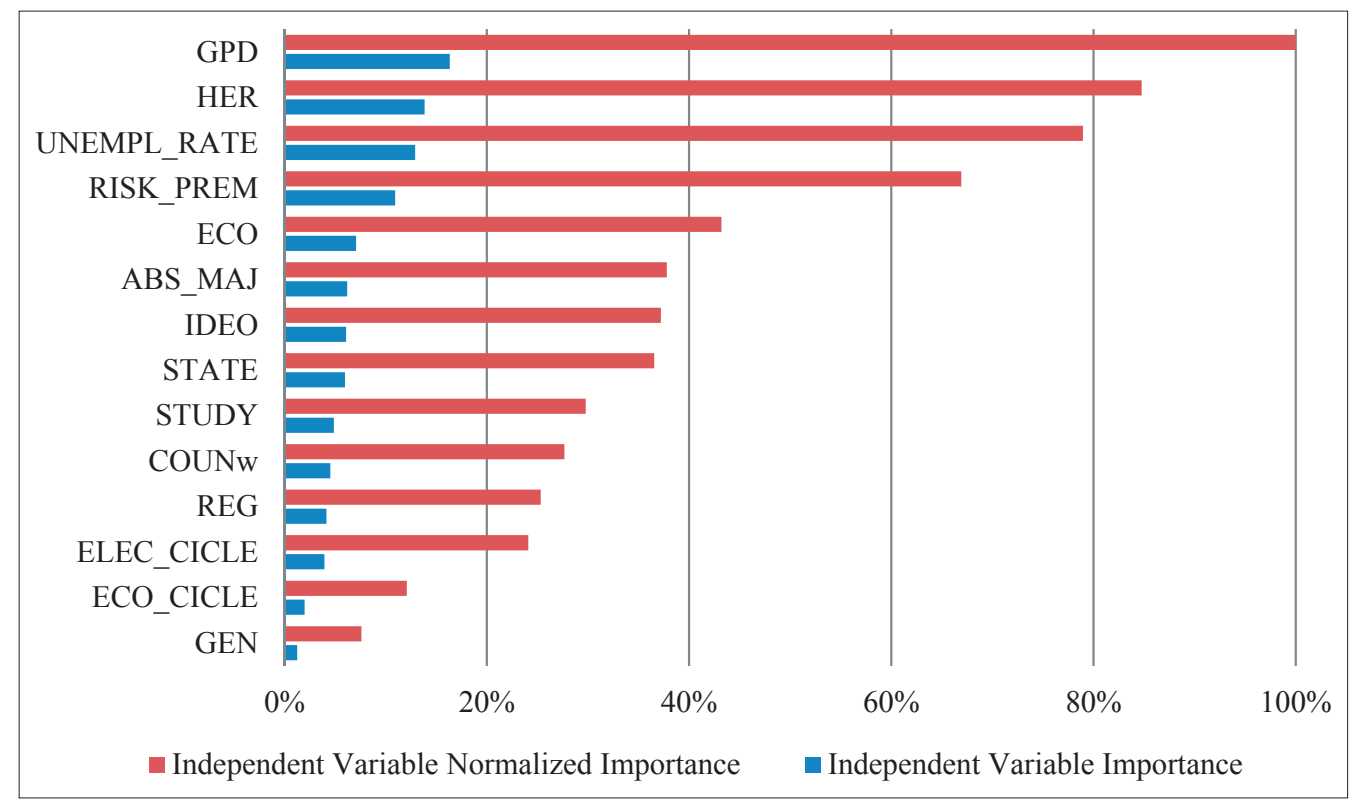

Figure 1: Normalized importance of the variables in MLP

Source: The authors

The results obtained for Model 2, with each of the two techniques used (Table 3), show that four variables are of a systemic nature and four are political, which confirms the joint, balanced impact of both types of factors on PD. However, if we consider the number of variables of each type, the representativeness of the systemic variables (four out of five) is greater than that of the idiosyncratic ones (four out of ten), which suggests that the impact of non-controllable factors is greater than that of controllable ones.

Our analysis by individual variables shows that the mayor's having a university degree in an economics-related subject is a significant variable, with a sign equal to that expected; in other words, when a local government mayor has this educational background there is a lower probability of default. This finding advances upon the conclusions of previous studies (Benito, Bastida and Muñoz, 2010; Guillamón, Bastida and Benito, 2011), which did not examine the relationship with PD, but only analyzed the volume of debt.

Second, we find that the proportion of female councilors in the municipal corporation is inversely related to $\mathrm{PD}$, which implies that increasing the number of women in the LG team could reduce the risk of default. Previous research has only reported evidence of the effect of this variable on tax revenues (Geys and Revelli, 2011), and therefore our results are novel, corroborating the specific influence of female representation in the municipal government on the risk of PD.

With respect to political ideology, we find that LGs with a progressive ideology are associated with a greater $\mathrm{PD}$, which extends the conclusions of previous research 
Table 4: Classification matrix

\begin{tabular}{|c|c|c|c|c|}
\hline \multicolumn{5}{|c|}{ LOGIT PANEL DATA (MODEL 1) } \\
\hline & \multirow[t]{3}{*}{ Observed } & \multicolumn{3}{|c|}{ Prediction } \\
\hline & & \multicolumn{2}{|l|}{ Y } & \multirow{2}{*}{ Correct percentage } \\
\hline & & Non-Default & Default & \\
\hline \multirow{2}{*}{ Y } & Non-Default & 266 & 136 & $66.17 \%$ \\
\hline & Default & 137 & 349 & $71.81 \%$ \\
\hline \multicolumn{2}{|c|}{ Overall percentage } & & & $69.26 \%$ \\
\hline \multicolumn{5}{|c|}{ LOGIT PANEL DATA (MODEL 2) } \\
\hline \multirow{3}{*}{\multicolumn{2}{|c|}{ Observed }} & \multicolumn{3}{|c|}{ Prediction } \\
\hline & & \multicolumn{2}{|l|}{ Y } & oct norcontage \\
\hline & & Non-Default & Default & ourlect percentiage \\
\hline \multirow{2}{*}{ Y } & Non-Default & 292 & 110 & $72.64 \%$ \\
\hline & Default & 137 & 349 & $71.81 \%$ \\
\hline \multicolumn{2}{|c|}{ Overall percentage } & & & $72.18 \%$ \\
\hline
\end{tabular}

\begin{tabular}{|c|c|c|c|c|}
\hline \multicolumn{5}{|c|}{ NEURAL NETWORK (MODEL 1) } \\
\hline \multicolumn{2}{|r|}{ Observed } & \multicolumn{3}{|c|}{ Prediction } \\
\hline & & \multicolumn{2}{|l|}{ Y } & \multirow{2}{*}{ Correct percentage } \\
\hline & & Non-Default & Default & \\
\hline \multirow{2}{*}{ Y } & Non-Default & 291 & 111 & $72.39 \%$ \\
\hline & Default & 129 & 357 & $73.46 \%$ \\
\hline \multicolumn{2}{|c|}{ Overall percentage } & & & $72.97 \%$ \\
\hline \multicolumn{5}{|c|}{ NEURAL NETWORK (MODEL 2) } \\
\hline \multirow{3}{*}{\multicolumn{2}{|c|}{ Observed }} & \multicolumn{3}{|c|}{$\begin{array}{l}\text { Prediction } \\
\end{array}$} \\
\hline & & \multicolumn{2}{|l|}{$Y$} & Conmet nomenton \\
\hline & & Non-Default & Default & Correct percentage \\
\hline \multirow{2}{*}{ Y } & Non-Default & 299 & 103 & $74.38 \%$ \\
\hline & Default & 120 & 366 & $75.31 \%$ \\
\hline \multicolumn{2}{|c|}{ Overall percentage } & & & $74.89 \%$ \\
\hline
\end{tabular}

Source: The authors

findings (Balaguer-Coll, Prior and Tortosa-Ausina, 2016; Bel and Miralles, 2010) according to which progressive governments are more likely than conservative ones to adopt expansive spending policies, giving rise to higher volumes of debt and greater difficulties in meeting payment obligations.

With respect to public policies, a comprehensive analysis of government solvency on the basis of default risk should include, as well as variables reflecting the decisions of policymakers and citizens (idiosyncratic variables), systematic factors whose behavior is not subject to these circumstances, but which nevertheless should be understood and taken into account, in order to effectively manage credit risk. Our findings suggest that policy makers need to be well informed about the detrimental effects on public ser- 
vices of an increased risk of municipal default, which may occur when policymakers do not have a background in economics, when the government has a progressive ideology and when female councilors are under-represented in the corporation. If politicians are sensitive to the possible negative consequences of these circumstances, a more prudent and viable approach may be adopted in their financial planning.

With respect to the influence of the systemic variables considered, we identify four that may affect LG credit risk. As shown in Table 3, the first systemic variable considered is that of the growth rate of the national economy (i.e., GDP). In this respect, a significant, inverse association was observed; this was in line with our expectations and suggested that a fall in the GDP may increase LG credit risk. This finding contrasts with previous studies (Arbatli and Escolano, 2015; Balaguer-Coll, Prior and Tortosa-Ausina, 2016), which reported the influence of GDP on the volume of government debt, but did not study its effect on PD. Another statistically significant variable is the national unemployment rate. This variable, too, was found to be inversely associated with PD, which is in accordance with previous research findings (Arbatli and Escolano, 2015; Navarro-Galera et al., 2015).

The third significant systemic variable is the national risk premium, which presented a positive sign, as expected. This result empirically corroborates the conclusions of Aldasoro and Seiferling (2014), the European Commission (2015) and previous research (Mackey, 2014), and suggests that an increase in the risk of sovereign debt is eventually reflected in a greater PD in LGs, given the interrelations between local, regional, and central governments, and the current and capital transfers made. In line with Gaillard (2009), Balaguer-Coll, Prior and Tortosa-Ausina (2016) and Navarro-Galera et al. (2015), we assume this factor is non-controllable. Our analysis also shows that the electoral cycle may influence the default risk of local governments (specifically that PD may increase during pre-election periods) as observed previously by Blais and Nadeau (1992).

These findings for the systematic variables are relevant to the decisions of policy makers. These variables cannot be directly controlled by politicians and their significance leads us to consider that annual budgets should be prepared taking into account the foreseeable evolution of the macroeconomic variables, by means of multiannual planning techniques and scenario analyses. Trends in these variables should be taken as warning signs, with the potential to impact on access to bank credit and on the cost of borrowing.

Finally, these findings may be useful for managers in other countries, too. The significance of the idiosyncratic variables considered (the ideology of the governing party, the proportion of female councilors and the educational background of the mayor) is in line with the conclusions of previous work on debt and financial sustainability, carried out in countries such as Netherlands, Finland, Austria, Switzerland, Italy, Germany or Belgium (Jennings, 1983; Geys and Revelli, 2011). In addition, the explanatory variables (such as unemployment and the risk premium) were selected taking into account previous research in this field in countries such as Norway, Italy or Canada 
(Arbatli and Escolano, 2015; Blais and Nadeau, 1992), bearing in mind that their effects tend to be generalized.

\section{Conclusions}

The present study highlights the interconnection between political decisions and economic-financial management. The empirical results obtained provide novel evidence of the influence of political and systemic variables on the risk of LG loan default. The results show that some political variables (the mayor's lack of economics-related university studies, a low proportion of female councilors in the municipal corporation, the progressive ideology of the governing party and ideological alignment between the municipal and the regional government) may contribute to increasing the probability of loan default, thus heightening the financial risk and problems of insolvency.

Our joint analysis of political and systemic variables shows that the latter are also relevant to the risk of default. Thus, a rise in the national unemployment rate and in the sovereign risk premium, together with the impact of the electoral cycle and of declining economic growth, may all increase PD in local government. These findings suggest that the influence of political factors, which in turn depend on the decisions taken by citizens in electoral processes, may be affected by the evolution of systemic variables, which do not depend on these decisions.

This finding represents the empirical corroboration of statements by international organizations (European Commission, IMF and the World Bank) and of prior research in this field, in that the insolvency problems facing governments arise from both controllable and non-controllable factors, such as systemic variables.

Our joint study of the influence of political and systemic variables on credit risk provides more complete and representative results than those derived from the individual analysis of political factors. The incorporation of systemic variables into the analysis has produced a very significant advance in our understanding of these questions. Thus, the financial risk behavior of LGs is subject to considerable uncertainty and the probability of default is affected by variables whose evolution is beyond the immediate control of policymakers, such as changes in the unemployment rate, in the risk premium and in the growth of the national economy.

In short, although systemic variables - which escape the control of citizens and of local governments - exert a significant influence on default risk, the political decisions of voters, expressed in electoral processes, also impact on this risk, as do factors such as the political ideology of the governing party, the educational background of the mayor and the gender of municipal councilors.

Finally, our findings represent an advance on those of previous research into the question of government debt. Although earlier studies have reported the impact of political ideology and of ideological alignment between local and regional government on the volume of LG debt, our findings specifically identify the influence of these factors on the risk of debt default. On the other hand, we found no evidence of the influence on the risk of default by the mayor's gender or education background, 
by political fragmentation or by the governing party's ideological alignment with the central government.

These findings can be very useful when policy makers must take concrete decisions, for the following reasons: (a) in the financial planning of public policies, the effect of variables that are not controllable by the rulers must be recognized, measured and included in the budget; (b) to avoid or mitigate the risk of default, policy makers must be well informed of the detrimental effects on the viability of public services of factors such as the mayor's lack of university studies in an economics-related subject, governance by a party with a progressive ideology and the under-representation of female councilors; (c) the annual budget must be prepared taking into account the foreseeable evolution of macroeconomic variables, using multiannual planning techniques and scenario analyses; (d) the effect of political variables on the risk of default may be contrary to that of the systematic variables, and this in turn would impact on the financial planning of public policies.

\section{References:}

1. Aldasoro, I. and Seiferling, M., 'Vertical Fiscal Imbalances and the Accumulation of Government Debt', 2014, IMF Working Paper no 14/209, [Online] available at https://www.imf. org/external/pubs/ft/wp/2014/wp14209.pdf, accessed on March 15, 2019.

2. Arbatli, E. and Escolano, J., 'Fiscal Transparency, Fiscal Performance and Credit Ratings', 2015, Fiscal Studies, vol. 36, no. 2, pp. 237-270.

3. Ashworth, J., Geys, B. and Heyndels, B., 'Government Weakness and Local Public Debt Development in Flemish Municipalities’, 2005, International Tax and Public Finance, vol. 12, no. 4, pp. 395-422.

4. Balaguer-Coll, M.T., Prior, D. and Tortosa-Ausina, E., 'On the Determinants of Local Government Debt: Does One Size Fit All?', 2016, International Public Management fournal, vol. 19, no. 4, pp. 237-270.

5. Bank of Spain, Boletín Estadístico del Banco de España, Madrid, 2014.

6. Bastida, F., Benito, B. and Guillamón, M.D., 'An Empirical Assessment of the Municipal Financial Situation in Spain', 2009, International Public Management fournal, vol. 12, no. 4, pp. 484-489.

7. BCBS, 'Basel II: International Convergence of Capital Measurement and Capital Standards: A Revised Framework - Comprehensive Version', 2006. [Online] available at https://www. bis.org/publ/bcbs128.htm, accessed on March 15, 2019.

8. Beetsma, R.M.W.J. and Vermeylen, K., 'The Effect of Monetary Unification on Public Debt and Its Real Return', 2007, Public Choice, vol. 133, no. 3/4, pp. 393-415.

9. Bel, G. and Miralles, A., 'Choosing between Service Fees and Budget Funding to Pay for Local Services: Empirical Evidence from Spain', 2010, Environment and Planning C: Politics and Space, vol. 28, no. 1, pp. 54-71.

10. Benito, B., Bastida, F. and Muñoz, M.J., 'Factores explicativos de la presión fiscal municipal', 2010, Revista de Contabilidad-Spanish Accounting Review, vol. 13, no. 2, pp. 239-283.

11. Blais, A. and Nadeau, R., 'The Electoral Budget Cycle', 1992, Public Choice, vol. 74, no. 4, pp. 389-403. 
12. Bluhm, C. and Overbeck, L., 'Systematic Risk in Homogeneous Credit Portfolios', in Bol, G., Nakhaeizadeh, G., Rachev, S.T., Ridder, T. and Vollmer, K.H. (eds.), Credit Risk: Measurement, Evaluation and Management, Heidelberg: Physica-Verlag Springer-Verlag Company, 2003, pp. 35-48.

13. Bonfim, D., 'Credit Risk Drivers: Evaluating the Contribution of Firm Level Information and of Macroeconomic Dynamics', 2009, Journal of Banking \& Finance, vol. 33, no. 2, pp. 281-299.

14. Cabaleiro-Casal, R. and Buch-Gomez, E., 'Public Spending Policies and Budgetary Balances: Evidence from Spanish Municipalities', 2015, Lex Localis-Journal of Local Self-Government, vol. 13, no. 4, pp. 973-994.

15. Castrén, O., Dées, S. and Zaher, Z., 'Stress-testing Euro Area Corporate Default Probabilities Using a Global Macroeconomic Model', 2010, Journal of Financial Stability, vol. 6, no. 2, pp. 64-78.

16. Castro, V., 'Macroeconomic Determinants of the Credit Risk in the Banking System: The Case of the GIPSI', University of Coimbra, GEMF Working Paper Series no. 2013-12, 2013, [Online] available at https://ideas.repec.org/p/gmf/wpaper/2013-12..html, accessed on March 15, 2019.

17. Council of the European Union, Council Directive 2011/85/EU of 8 November 2011 on requirements for budgetary frameworks of the Member States, published in the Official Journal of the European Union OJ L 306 from 23.11.2011.

18. Elgin, C. and Uras, B.R., 'Public Debt, Sovereign Default Risk and Shadow Economy', 2013, fournal of Financial Stability, vol. 9, no. 4, pp. 628-640.

19. European Commission, 'Fiscal Sustainability Report', 2012, European Economy 8/2012, [Online] available at https://ec.europa.eu/economy_finance/publications/european_econ omy/2012/pdf/ee-2012-8_en.pdf, accessed on March 15, 2019.

20. European Commission, 'Making the Best Use of the Flexibility within the Existing Rules of the Stability and Growth Pact', 2015, COM (2015) 12 final, [Online] available at https://eurlex.europa.eu/legal-content/EN/TXT/PDF/?uri=CELEX:52015DC0012\&from=EN, accessed on March 15, 2019.

21. Federal Accounting Standards Advisory Board, 'FASAB Handbook of Federal Accounting Standards and Other Pronouncements, as Amended', 2018, [Online] available at https:// files.fasab.gov/pdffiles/2018_fasab_handbook.pdf, accessed on March 15, 2019.

22. Fundación La Caixa, Memoria de Sostenibilidad 2012, Barcelona, 2014.

23. Gaillard, N., 'The Determinants of Moody's Sub-sovereign Ratings', 2009, International Research fournal of Finance and Economics, vol. 31, pp. 196-209.

24. Galli, E. and Padovano, F., 'A Comparative Test of Alternative Theories of the Determinants of Italian Public Deficits (1950-1998)', 2002, Public Choice, vol. 113, no. 1/2, pp. 37-58.

25. Geys, B. and Revelli, F., 'Economic and Political Foundations of Local Tax Structures: An Empirical Investigation of the Tax Mix of Flemish Municipalities', 2011, Environment and Planning C: Government and Policy, vol. 29, no. 3, pp. 410-427.

26. Gordy, M.B., 'A Risk-factor Model Foundation for Ratings-based Bank Capital Rules', 2003, Journal of Financial Intermediation, vol. 12, no. 3, pp. 199-232.

27. Guillamón, M.D., Bastida, F. and Benito, B., 'The Determinants of Local Government's Financial Transparency', 2011, Local Government Studies, vol. 37, no. 4, pp. 391-406. 
28. Hausman, J.A., 'Specification Test in Econometrics', 1978, Econometrica, vol. 46, no. 6, pp. 1251-1271.

29. IGAE, Avance de la actuación económica y financiera de las administraciones Públicas 2013, Madrid, 2014.

30. Jacobson, T., Lindé, J. and Roszbach, K., 'Firm Default and Aggregate Fluctuations', 2013, Fournal of the European Economic Association, vol. 11, no. 4, pp. 945-972.

31. Jennings, M.K., 'Gender Roles and Inequalities in Political Participation: Results from an Eight-nation Study', 1983, Western Political Quarterly, vol. 36, no. 3, pp. 364-385.

32. Lago, I. and Lago, S., 'Does the Internationalization of Party Systems Affect the Composition of Public Spending?', 2009, Economics of Governance, vol. 10, no. 1, pp. 85-98.

33. Local Government Association of South Australia, 'South Australia Model Financial Statements', 2019, [Online] available at https://www.lga.sa.gov.au/webdata/resources/files/ ConsultationModel2019.pdf, accessed on June 15, 2019.

34. Mackey, T., 'An Analysis of Spain's Sovereign Debt Risk Premium', 2014, The Park Place Economist, vol. 22, no. 1, pp. 67-77.

35. Massolo, A., 'Mujeres en el espacio local y el poder municipal', 1991, Revista Mexicana de Sociología, vol. 58, no. 3, pp. 133-144.

36. Mileris, R., 'Macroeconomic Determinants of Loan Portfolio Credit Risk in Banks', 2012, Inzinerine Ekonomika-Engineering Economics, vol. 23, no. 5, pp. 496-504.

37. Moody's Investors Service, A Methodology of Rating to Local and Regional Governments, Moody's, 2013.

38. Moody's Investors Service, Regional and Local Governments outside the US, Moody's, 2008.

39. Navarro-Galera, A., Buendía-Carrillo, D., Lara-Rubio, J. and Rayo-Cantón, S., 'Do Political Factors Affect the Risk of Local Government Default? Recent Evidence from Spain', 2017, Lex Localis - Journal of Local Self-Government, vol. 15, no. 1, pp. 43-66.

40. Navarro-Galera, A., Rayo-Cantón, S., Lara-Rubio, J. and Buendía-Carrillo, D., 'Loan Price Modelling for Local Governments Using Risk Premium Analysis', 2015, Applied Economics, vol. 47, no. 58, pp. 6257-6276.

41. Piotrowski, S.J. and Van-Ryzin, G.G., 'Citizen Attitudes toward Transparency in Local Government', 2007, American Review of Public Administration, vol. 37, no. 3, pp. 306-323.

42. Rösch, D., 'Correlations and Business Cycles of Credit Risk: Evidence from Bankruptcies in Germany', 2003, Financial Markets and Portfolio Management, vol. 17, no. 3, pp. 309-331.

43. Roubini, N. and Sachs, J., 'Government Spending and Budget Deficits in the Industrial Economies', NBER Working Papers no. 2919, Cambridge: National Bureau of Economic Research Inc., 1989, [Online] available at https:/www.nber.org/papers/w2919, accessed on March 15, 2019.

44. Ryan, C., Pini, B. and Brown, K., 'Beyond Stereotypes: An Explanatory Profile of Australian Women Mayors', 2005, Local Government Studies, vol. 31, no. 4, pp. 443-448.

45. Solé-Ollé, A. and Sorribas-Navarro, P., 'The Effects of Partisan Alignment on the Allocation of Intergovernmental Transfers. Differences-in-differences Estimates for Spain', 2008, Journal of Public Economics, vol. 92, no. 12, pp. 2302-2319.

46. Standard \& Poor's, Default, Transition, and Recovery: 2008 Default and Transition Study for International Local and Regional Governments, Standard \& Poor's, 2009.

47. Standard \& Poor's, Sovereign Government Rating. Methodology and Assumptions, Global Credit Portal. Rating Directs, Standard \& Poor's, 2011. 
48. Train, K.E., Discrete Choice Methods with Simulation, Cambridge University Press, 2003.

49. US Department of the Treasury, Initiatives about Debt Limit, US Department of the Treasury, 2013.

50. Van Der Burgt, M.J., 'Wavelet Analysis of Business Cycles for Validation of Probability of Default: What Is the Influence of the Current Credit Crisis on Model Validation?', 2009, The fournal of Risk Model Validation, vol. 3, no. 1, pp. 3-22.

51. World Bank Group, 'Worldwide Governance Indicators', 2015, [Online] available at http:// info.worldbank.org/governance/wgi/, accessed on March 15, 2019. 